\title{
The perceived benefits derived from visits to a super regional shopping centre: an exploratory study
}

\author{
Nic S. Terblanché \\ Department of Business Management, University of Stellenbosch, Private Bag X1, Matieland, 7602 South Africa
}

Received October 1999

\begin{abstract}
Studies that aim to identify shopper types typically attempt to identify a limited set of differentiated shopper types to which retailers can target differentiated marketing efforts. The identification of shopper segments patronising large shopping centres. have been surprisingly underresearched. This study investigated the perceived benefits of shopping at a large super re-
gional shopping centre and three distinct benefit dimensions emerged.
\end{abstract}

\section{Introduction}

Initially shopping centres were established in suburbs away from central business districts to be close to their customers. Shopping centre developers reacted to the poverty of time experienced by consumers by building increasingly bigger shopping centres to meet consumers' demand for one-stop shopping. Today shopping centres satisfy a number of consumer needs and wants. Understanding consumers' perception of benefits derived from visits to shopping centres can help retailers and developers define the character and image of a shopping centre in ways that will enhance positive perceptions of such benefits. Over time competition among shopping centres have also led to changes in the design and tenant mixes of shopping centres with the intention of appealing to the underlying motives other than functional motives. These include shopping centres that focus on entertainment or particular themes. All of these attempts illustrate the marketing efforts that aim to draw customers to large shopping centres. The effectiveness of these diverse marketing formats has not been proven yet (Shim \& Eastlick, 1998: 140). Despite this lack of evidence on effectiveness, the shopping centre has transcended its initial role as an economic entity to become community centres for social and recreational activity (Bloch, Ridgway \& Dawson, 1994: 24). In short, shopping centres do play major roles in the lifestyles of consumers. Traditionally department stores and large supermarkets fulfilled the role of anchor tenants in large shopping centres. Today shoppers demand more entertainment. Food courts, restaurants, cinemas, children's play areas, interactive entertainment, social use areas, relaxation spaces and promotional areas can now all fulfil the role of an anchor in a shopping centre (Watt, 1999: 7).

\section{Changed role of shopping centres}

Shopping centres became increasingly larger. An explanation for this is that initially shopping centres focused on the provision of one-stop shopping convenience. Large shopping centres today attempt to offer recreational, aesthetic, entertainment and social experiences for their visitors. Variety in dining places, movie theatres, service providers, exhibitions and shows are evidence of the greater number of experiences offered by large shopping centres. Various studies found that the objective of much consumption activity is to obtain satisfying experiences rather than goods or services per se (Hirchman, 1984; Hirchman \& Holbrook, 1982; Holbrook \& Hirchman, 1982). In the context of shopping, a location (such as a large shopping centre) may therefore itself be a source of pleasurable experiences consumed by visitors (Bloch, Ridgway \& Dawson, 1994: 25). Shopping in large shopping centres can also be viewed as the type of activity which consumers will rather undertake themselves instead of transferring the responsibility thereof to someone else to perform it on their behalf. The reason for this is because the consumer benefits from the experiences of the activity (Darden \& Dorsch, 1990: 302). Because shopping centres have increasingly become more than assemblages of shops, the study of shopping centre-related shopping benefits could be of use to those who are involved in the planning, design and management of shopping centres.

\section{Shopper types}

Various attempts have been made to identify distinct shopper types. The major purpose underlying these attempts, is to identify a limited number of relatively homogeneous shopper types to which retail management can direct differentiated marketing offers. The seminal work of Stone (1954) can be regarded as the first attempt aimed at the identification of shopper typologies. Most of the studies undertaken so far have dealt with the identification of or explanation of the behaviour of shoppers, without particular reference to the shopping venue. Feinberg \& Meoli (1991: 426) argue that, despite the significance of shopping centres in society, one would be 'hard pressed to find a scholarly treatment of shopping centres (malls)' in the academic journals. Even within the field of retail research, the emphasis has primarily been upon the shop rather than the shopping centre as the unit of analysis (Bloch, Ridgway \& Dawson, 1994: 25). Evans, Christiansen \& Gill (1996: 216) also point out that scholarly research in particular has rarely focused on shopping centre features, as opposed to shop features. For instance, it was only fairly recently that pioneers such as Bloch, Ridgway \& Dawson (1994) and Roy (1994) initiated research on shopping and related behaviour in shopping centres. 


\section{Objectives}

The primary objective of this study is to measure the impact of certain benefit dimensions, based on the perceived benefits that consumers enjoy when visiting a super regional shopping centre, on shopping centre patronage. From a shopping centre manager's or owner's viewpoint, the identification of such benefit dimensions could be useful for building a strategy that will attract consumers and thereby enhancing the possibility to generate sales. The justification for a study of this nature lies in the role that the shopping centre plays in the life of consumers. Shopping centres which, in a certain sense, can be regarded as small scale business districts, are not only visited for functional shopping, they also appeal to a number of other benefits such as recreation, socialisation and convenience (Darden \& Dorsch, 1990; Evans, Christiansen \& Gill, 1996; Babin, Darden \& Griffin, 1994; Bellenger \& Korgaonkar, 1980). A super regional shopping centre was selected as focus of this study because of its scale and size. A super regional shopping centre offers a wide and diverse range of products, services and experiences to consumers. Four benefit dimensions were investigated in this study. The reasons for the selection of these four dimensions are dealt with in the next paragraph. The following four dimensions were included in this study:

- Functional

- Recreational

- Socialising

- Convenience

Specific advantages that can be gained from a study of this nature are the inputs it can provide for decision making related to the design, management or planning of the following:

- Tenant mix;

- Promotional activities;

- Location and size of shopping and non-shopping areas in the shopping centre; and

- Positioning of the centre to differentiate it from competition.

\section{Benefit dimensions studied}

The first potential dimension, namely functional benefits, is included in the study because various studies identified functional (also known as economic or functional economic) as a characteristic of not only shoppers themselves but also of their orientation towards shopping (Stone, 1954; Darden \& Reynolds, 1971; Bellenger \& Korgaonkar, 1980; Westbrook \& Black, 1985; Roy, 1994; Babin, Darden \& Griffin, 1994; Bergadaà, Faure \& Perrien, 1995). The elements of a shopping centre, especially a super regional shopping centre, that could satisfy a consumer's demand for functionality are typically:

- the saving of costs because a consumer does not have to travel to different shops for shopping;

- the concentration of complementary and competing shops that enable a consumer to readily compare prices and quality; and

- the amount of diverse product and service information available at a shopping centre.

The recreational benefit dimension has, similar to the functional benefit dimension, also received a fair amount of attention in research (Stephenson \& Willet, 1969; Bellenger \&
Korgaonkar, 1980; Westbrook \& Black, 1985; Sproles \& Kendall, 1986; Roy, 1994; Babin, Darden \& Griffin, 1994; Finn, McQuitty \& Rigby, 1994; Bergadaà, Faure \& Perrien, 1995). Shopping centres typically offer consumers a wide range of opportunities for recreation. On the one hand one finds facilities specifically designed for recreation such as movie theatres, rest areas and screens showing cartoons or sport events. On the other hand consumers visit shopping centres for exercise or window-shopping.

The social benefit dimension resemble those found in most previous shopping typology studies such as those of Tauber (1972), Westbrook \& Black (1985), Bloch, Ridgway \& Dawson (1994) and Feinberg, Meoli \& Sheffler (1989). The aforementioned studies suggest that social motives and the opportunity to satisfy social needs may be particularly strong in the context of shopping centres. When shopping centres are compared with free-standing shops, shopping centres offer a greater diversity of opportunities to socialise due to the presence of open spaces, benches, food courts and promotional areas.

The fourth potential dimension, namely convenience benefits, was included because of the importance of convenience in shopping for consumers. Initially shopping centres developed to give meaning and content to the concept of one-stop shopping and to provide consumers with the facilities to enhance one-stop shopping. The well-planned and managed shopping centre can be regarded as a major facilitator in shopping convenience because of the concentration of shops, ample parking, high accessibility and controlled climate in the shopping centre. In terms of one-stop shopping, shopping centres, especially those large ones high up in the shopping centre hierarchy such as super regionals must be 'close to the ultimate' for consumers. It is especially the destination shopper for whom the convenience benefit could be expected to be very important (London, 1992: 52).

\section{Methodology}

The sample consisted of respondents who visited a super regional shopping centre. The shopping centre has $96000 \mathrm{~m}^{2}$ of gross leasable area, 280 shops, 33 restaurants and other fast food outlets and ten cinemas. It also houses branches of banks, a public library and two service stations. Data were collected on-site as this was considered essential for obtaining accurate responses from shoppers. It must be pointed out that the respondents were ipso facto selected by the fact that they patronised this particular shopping centre. Shoppers were intercepted while they were on their way out but still inside the covered area of the shopping centre. All the entrances and exits were manned and interviewers approached respondents on their way out. The procedure for selection of a respondent was as follows: every fourth shopper leaving the shopping centre was approached and requested to participate in the survey. If a shopper refused, the next shopper was approached, after which every fourth shopper was approached again. Employees of the shopping centre or doing any other business in the shopping centre. were excluded from the study. The interviews took place on a Friday afternoon, Saturday morning and the afternoons of a Monday, Wednesday and a Thursday. These times and days were selected so that all the major types of shoppers, that 
patronise the shopping centre, as established from a previous study undertaken by the shopping centre owners, are included in the sample. Data were gathered by way of a structured questionnaire and 1407 questionnaires were completed. A total of 1365 fully completed questionnaires were used for data analysis. The sample represents a proportional volume of the shoppers that patronise the shopping centre. The lower cut off age for respondents was 20 years.

\section{Measuring instrument}

The questionnaire used as measuring instrument consists of three sections. The first section contains 25 items dealing with benefits derived from visiting a shopping centre. The 25 items were believed to measure the four benefit dimensions. Respondents were required to respond to these statements linked to a 7-point Likert scale which indicate the extent to which they agree or differ with each statement. The scale was anchored by a value of 1 which represented 'strongly disagree' and a value of 7 which represented 'strongly agree'. Shopping patronage was measured by two items related to the amount of time spent and number of shops visited at the shopping centre. All items were positively phrased to avoid the use of items with mixed polarity (Herche \& Engelland, 1996).

Six items were used to measure the functional benefit dimension. The items were based on previous studies that also measured functionality. In particular, the items are from the works of Bergadaà, Faure \& Perrien (1995); Westbrook \& Black (1985); Dawson, Bloch \& Ridgway (1990); Babin, Darden \& Griffin (1994). The recreational benefit dimension was measured by seven items. These items were based on the research of Sproles \& Kendall (1986); Dawson, Bloch \& Ridgway (1990); Bergadaà, Faure \& Perrien (1995), Westbrook \& Black (1985); Bloch, Ridgway \& Dawson (1994);
Roy (1994). Six items were used to measure the social benefit dimension and these items originate from the work of Westbrook \& Black (1985); Bergadaà, Faure \& Perrien (1995); Shim \& Eastlick (1998) and Dawson, Bloch \& Ridgway (1990). The convenience benefit dimension is also measured by six items. Four of the items are based on the work of Lumpkin \& Hunt (1989) and Saegert, Hoover \& Hilger (1985). The other two items were self-generated to represent aspects such as air conditioning in shopping centres and use of automated teller machines available in shopping centres.

The second section of the questionnaire contains 16 activities which respondents could take part in whilst they are in the shopping centre. Respondents were required to indicate a yes or a no, depending on whether they did take part in a specific activity or not. The results of this section are not reported here. The third section of the questionnaire dealt with the biographical and shopping characteristics of respondents and the persons that accompanied them. The biographical and shopping characteristics of the respondents is set out in Table 1.

\section{Scale purification}

The scale purification process consisted of three distinct phases: an assessment of the underlying dimensionality of the instrument used (and thus also discriminant validity), using exploratory factor analysis, an assessment of reliability by calculating Cronbach alpha coefficients, and finally, a path analysis with latent variables.

\section{Dimensionality}

The first step was to assess whether the data do indeed contain four dimensions as suggested by the literature. For this purpose, a Maximum Likelihood Exploratory Factor Analysis was conducted specifying a Direct Quartimin

Table 1 Biographical and shopping characteristics of the respondents

\begin{tabular}{|c|c|c|c|c|c|}
\hline Gender & & & & $\begin{array}{r}\text { Male } \\
43 \%\end{array}$ & $\begin{array}{c}\text { Female } \\
57 \%\end{array}$ \\
\hline \multirow{2}{*}{ Age group in years } & $20-30$ & $31-40$ & $41-50$ & $51-60$ & $60+$ \\
\hline & $52 \%$ & $19 \%$ & $14 \%$ & $10 \%$ & $5 \%$ \\
\hline \multirow[t]{2}{*}{ Frequency of visits to the centre } & & Weekly & Bi-weekly & Monthly & Less than monthly \\
\hline & & $56 \%$ & $22 \%$ & $14 \%$ & $8 \%$ \\
\hline \multirow[t]{2}{*}{ Number of people in respondent's company } & & 1 & $2-3$ & $4-5$ & 6 or more \\
\hline & & $45 \%$ & $45 \%$ & $7 \%$ & $3 \%$ \\
\hline \multirow[t]{2}{*}{ Number of people in respondent's household } & & 1 & $2-3$ & $4-5$ & 6 or more \\
\hline & & $10 \%$ & $42 \%$ & $41 \%$ & $7 \%$ \\
\hline \multirow{2}{*}{ Travel time - in ininutes from home to centre } & Less than 5 minutes & $6-10$ & $11-20$ & $21-30$ & $30+$ \\
\hline & $17 \%$ & $39 \%$ & $22 \%$ & $11 \%$ & $11 \%$ \\
\hline \multirow{2}{*}{ Monthly incume of household* } & Less than R2500 & R2501-R5000 & R5001-R10 000 & R10 001-R15000 & R15000+ \\
\hline & $15 \%$ & $20 \%$ & $29 \%$ & $17 \%$ & $19 \%$ \\
\hline \multirow{2}{*}{ Time spend in the shopping centre } & & Less than 30 minutes & $31-60$ minutes & $60-120$ minutes & More than 2 hours \\
\hline & & $14 \%$ & $31 \%$ & $29 \%$ & $26 \%$ \\
\hline \multirow{2}{*}{ Number of shops visited during this trip } & & 1 & $2-4$ & $5-8$ & $8+$ \\
\hline & & $12 \%$ & $50 \%$ & $24 \%$ & $14 \%$ \\
\hline \multicolumn{6}{|l|}{$N=1365$} \\
\hline Only 1049 respondents & & & & & \\
\hline
\end{tabular}


oblique rotation (Jenrich \& Sampson, 1966) of the original factor matrix.

As several of the original 25 items did not load a significant extent $(0.40)$ in several solutions or did not demonstrate sufficient discriminant validity by loading on more than one factor, they were deleted as suggested by Churchill (1995). After several factor solutions had been considered, the most interpretable one to emerge was the three-factor solution shown in Table 2. The factor analysis results reported in Table 2 confirms that the questionnaire used to measure the various benefits described in the literature, contain three separate constructs.

Table 2 Exploratory factor analysis results

\begin{tabular}{lccc}
\hline & Factor 1 & Factor 2 & Factor 3 \\
\hline & Functional & Recreational & Social \\
\hline FINC 1 & 0.744 & & \\
HINC 2 & 0.579 & & \\
HUNC : & 0.569 & & \\
HUNC + & 0.562 & & \\
HUNC : & 0.552 & & \\
FUNC 6 & 0.480 & & \\
RIC 1 & & 0.720 & \\
RI:C 2 & & 0.573 & \\
REC 3 & & 0.557 & \\
REC 4 & & 0.508 & \\
REC 5 & & 0.506 & \\
REC 6 & & 0.475 & \\
SOC 1 & & & 0.810 \\
SOC 2 & & & 0.592 \\
SOC 3 & & & 0.510 \\
\hline Iigen values & 2.248 & 1.983 & 1.385 \\
\hline
\end{tabular}

According to Table 2 fifteen of the original 25 items loaded to a significant extent on one of three clearly identifiable segments. These benefit dimensions are termed functional, recreational and social. No empirical support could be found for the envisaged convenience benefit dimension. One of the items expected to measure convenience (re-coded FUNC 1) did, however, load to a significant extent $(0.744)$ on the functional dimension.

\section{Reliability}

The remaining 15 items were then, as suggested by Churchill (1995), subjected to an internal reliability analysis using the computer program STATISTICA 6.0 (Statsoft Inc, 1995). Cronbach alpha values reported in Table 3 show that all the underlying dimensions of the construct 'benefits related to patronising a super regional shopping centre' are measured by an instrument with sufficient reliability $(\propto>0.7)$ and that the Cronbach alpha of the entire instrument is 0.983 .

\section{Path analysis}

The proposed instrument to measure the benefit dimensions related to consumers that patronise super regional shopping centres (Table 4) was then subjected to a path analysis
Table 3 Internal reliability results

\begin{tabular}{lc}
\hline Dimensions & $x$ \\
\hline Recreational & .975 \\
Functional & .959 \\
Social & .941 \\
Overall & .983 \\
\hline
\end{tabular}

(structural equation modelling) (Browne \& Mels, 1990). The objective of this analysis was to determine to what extent each one of the underlying dimensions identified in Table 2 (recreational, functional and social) predict actual patronage to a super regional shopping centre. The results, set out in Table 5, suggest that the model in Figure 1 represents a reasonable fit to the data (Hair. Tatham, Black \& Anderson. 1998: 656). All the indices reported in Table 5 meet or exceed the minimum standards suggested by Hair et al. (1998). The path analysis also provides some evidence of construct validity of the instrument (Tull \& Hawkins, 1993: 318).

The results of this analysis, set out in Table 5, suggest that the model in Figure 1 represents a reasonable fit to the data (Steiger \& Lind, 1980) as the RMSEA lies between 0.05 and 0.08 .

Figure 1 shows that the pursuance of recreational benefits by consumers exert the strongest impact on the patronage behaviour of the consumers in this sample $(0.510 ; p<0.01)$. In other words, the more important recreation benefits the higher the level of patronage. Contrary to expectations functional benefits exert a negative. albeit relatively small negative.

Table 4 Items to measure the benefit dimensions related to consumers that patronise a super regional shopping centre

Functional shoppers

FUNC I A visit to the centre is convenient because one can shop. visit the bank. have a meal and see a movic in one trip.

FUNC 2 I save costs because I do not have to drive to various shops

FUNC 3 The architecturc and interior design of the centre make it pleasant to spend time here

FUNC 4 My expectations are usually accomplished when I visit the centre.

FUNC 5 It is relaxing to enjoy a meal or a drink at the centre

FUNC 6 The concentration of shops in the centre saves me shopping time

Recreational shoppers

\begin{tabular}{ll}
\hline REC I & I enjoy visiting the centre because I sce people. \\
REC 2 & I enjoy the crow ding of people in the centre. \\
REC 3 & Visiting the centre is a good way to relax. \\
REC 4 & I enjoy it to wander in the centre. \\
REC 5 & I enjoy to watch people in the centre. \\
REC 6 & It is a social occasion to shop with my friends at the centre. \\
\hline SOcial shoppers \\
\hline SOC 1 & I meet new people at the centre. \\
SOC 2 & When I visit the centre. I meet people. \\
SOC 3 & I enjoy talking with sales people and other visitors at the centre
\end{tabular}


Table 5 Measures of fit of the model

\begin{tabular}{lc} 
RMSEA & 0.067 \\
$X^{2}$ & 623.21 \\
df & 87 \\
LISREL GFI & 0.938 \\
LISREL Adjusted GFI & 0.914 \\
Bentler-Bonnett Non-Formed Fit Index & 0.896 \\
RMR & 0.052 \\
\hline
\end{tabular}

impact on patronage. In other words, the more important functional benefits are to buyers the less likely they are to patronize a super regional shopping centre. The satisfaction of social needs or benefits, on the other hand, do not influence patronage at these types of retail outlets.

\section{Conclusions and implications for shopping centre management}

This study has shown that of the benefits studied, recreation appears to be the major benefit pursued by shoppers that patronise a super regional shopping centre. The findings in respect of functional and social benefits are contrary to the findings of previous research. It was expected that consumers would vary in the perceived benefits that bring them to a large shopping centre but the fact that convenience does not feature as a benefit is surprising because large super regional shopping centres offer much in this regard. However, when one considers the scale of the very big shopping centres such as the one in this study, certain characteristics of the centre might offer some explanation for the absence of convenience as a benefit. Large shopping centres provide vast parking areas because these centres mainly appeal to motor car oriented traffic. These vast open parking areas might be responsible for creating very long cognitive distances in consumers' minds. Large deck parking areas that appear cluttered and which were opened at the shopping centre shortly before the study was undertaken, could also be responsible for the formation of the perception in respect of convenience. The finding that functional benefits exert a negative impact on patronage lend support to this view. A possible further explanation for the non-featuring of convenience could be crowding and the stress certain consumers experience as a result of it. It is possible that the scale and architectural features can create feelings of crowding for some consumers. One can thus speculate that it appears as if there might be a size of shopping centre beyond which consumers do not perceive functional or convenience benefits anymore.

The findings of this study have, inter alia, certain implications for the positioning of a shopping centre. If a shopping centre is to be positioned as focusing on recreational shoppers, it would require more attention to ambience and the inclusion of related services such as movie theatres, restaurants and game parlours. Special events and exhibits might also cause recreational shoppers to visit a shopping centre more frequently. Recreational shoppers are important to the shopping centre industry and the recreational shopper seems to want more than other groups of shoppers. For existing centres it might be necessary to ensure that 'position' is constantly projected and communicated to the target market.

The fact that the respondents did not perceive functional and convenience benefits offered by visits to the shopping centre, might also have something to do with the "under

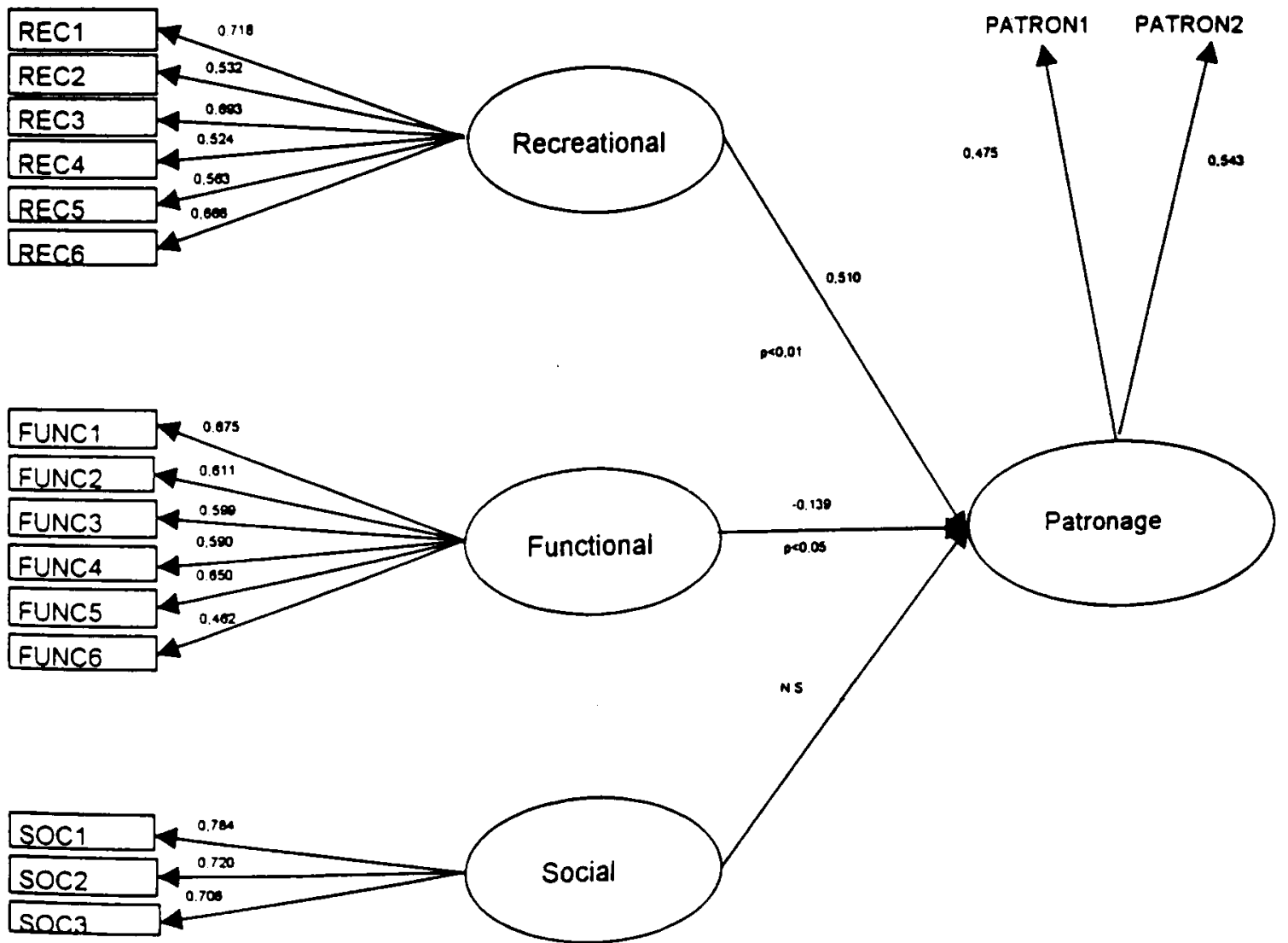

1) All path coefficients significant at $p<0,01$ unless indicated otherwise.

Figure $1_{\text {।) }}$ 
marketing' of such benefits by the shopping centre to its target market. Marketing communication of shopping centres tend to promote the 'vibe' and the 'experiences' of shopping centres. For instance, to draw functional shoppers or having existing shoppers perceiving the shopping centre as offering functional benefits, the cost and time-efficiency of visits to the shopping centre will have to be communicated. Shops that carry complementary items, high accessibility of the location and the variety offered by shops are additional aspects that would appeal to functional shoppers.

Although this study did not support previous findings with regard to the role of shopping centres providing social benefits to consumers, improved measures and future research may provide a better picture of how consumers vary in their perception of benefits offered by a large shopping centre. A variety of other criteria may be employed to further extend this work, for example, age or gender or other demographic characteristics of consumers. Younger consumers may, for instance, be more susceptible to social influence due to a desire to 'fit in' and patronise a shopping centre because their peers do. From a gender viewpoint it is possible that males may become more involved in shopping at shopping centres and shopping may become more of a means of social interaction to them.

\section{References}

Babin, B.J., Darden W.R. \& Griffin, M. 1994. Work and/or fun: measuring hedonic and utilitarian shopping value, Journal of Consumer Research, 20(4): 644-656.

Bellenger, D.N. \& Korgaonkar, P.K. 1980. Profiling the recreational shopper, Journal of Retailing, 56(3): 77-92.

Bergadaà, M., Faure C. \& Perrien, J. 1995. Enduring involvement with shopping, The Journal of Social Psychology, 135(1): 17-25.

Bloch, P.H., Ridgway N.M. \& Dawson, S.A. 1994. The shopping mall as consumer habitat, Journal of Retailing, 70(1): 23-42.

Browne, M.W. \& Mels, G. 1990. Ramona PC Users Guide. Pretoria: Human Sciences Research Council.

Churchill. G.A. (Jr.) 1995. Marketing research: methodological foundations. 6th ed. Forth Worth: Dryden Press

Darden, W.R. \& Dorsch, M.J. 1990. An action strategy approach to examining shopping behavior, Journal of Business Research, 21 : 289-308.

Dawson, S.. Bloch P.H., \& Ridgway, N.M. 1990. Shopping motives, emotional states and retail outcomes, Journal of Retailing, 66(4): 408-427.

Darden, W.R. \& Reynolds, F.D. 1971. Shopping orientations and product usage roles, Journal of Marketing Research, 8: 505-508.

Evans, K.R.. Christiansen, T. \& Gill, J.D. 1996. The impact of social influence and role expectations on shopping center patronage intentions, Journal of the Academy of Marketing Science, 24(3) 208-218.

Feinberg, R.A. \& Meoli, J. 1991. A brief history of the mall. In Holmon, R. \& Solomon, M. Eds. Advances in consumer research, Vol 18: 426-427. Provo, UT: Association for Consumer Research

Feinberg, R.A. \& Meoli, J. \& Sheffler, B. 1989. There's something social happening at the mall, Journal of Business and Psychology. 4(Fall): 49-63.

Finn, A., \& Louviere, J. 1990. Shopping-center patronage models, Journal of Business Research, 21: 259-275.

Finn, A., McQuity S., \& Rigby, J. 1994. Residents' acceptance and use of a mega-multi-mall: West Edmonton Mall evidence, International Journal of Research in Marketing, 11: 127-144.

Hair, J.F. (Jr.), Anderson, R.E., Tatham, R.L. \& Black. W.C. 1998 Multivariate data analysis. 5th ed. Upper Saddle River: Prentice Hall.

Herche, J. \& Engelland, B. 1996. Reversed-polarity items and scale unidimensionality, Journal of the Academy of Marketing Science, 24(4): 366-374.

Hirchman, E.C. \& Holbrook, M.B. 1982. Hedonic consumption: emerging concepts, methods, and propositions, Journal of Marketing, 46(Summer): 92-101

Hirchman, E.C. 1984. Experience seeking : a subjectivist perspective of consumption, Journal of Business Research, 12: 115-136.

Holbrook, M.B. \& Hirchman, E.C. 1982. The experiential aspects of consumption: consumer fantasies, feelings and fun, Journal of Consumer Research, 9(September): 132-140.

Jennrich, R.I. \& Sampson, P.F. 1966. Rotation for simple loadings, Psychometric, 31: 313-323.

London, M.N. 1992. The new convenience: seeking ways to make centers easier to shop, Chain Store Age Executive, 68(November): 52.

Lumpkin, J.R. \& Hunt, J.B. 1989. Mobility as an influence on retail patronage behaviour of the elderly: testing conventional wisdom, Journal of the Academy of Marketing Science, 17(Winter): 1-12.

Roy, A. 1994. Correlates of mall visit frequency, Journal of Retailing, 70(2): 139-161.

Saegert, J., Hoover, R.J. \& Hilger, M.T. 1985. Characteristics of Mexican American Consumers, Journal of Consumer Research, 12(June): 104-109.

Shim, S. \& Eastlick, M.A. 1998. The hierarchical influence of personal values on mall shopping attitude and behaviour, Journal of Retailing, 74(1): 139-160.

Sproles, G.B. \& Kendall, E.L. 1986. A methodology for profiling consumers' decision-making styles, The Journal of Consumer Af fairs, 20(2): 267-279.

Statsoft Inc. 1995. Statistica for Windows. Tulsa, OK: Statsoft Inc

Steiger, J.H. \& Lind, J.C. 1980. Statistically based tests for the number of common factors. Paper presented at the annual meeting of the Psychometric Society, lowa.

Stephenson, P.R. \& Willett, R.P. 1969. Analysis of consumers' retail patronage strategies. In McDonald, P.R. Ed. Marketing involvement in society and the economy. Chicago: American Marketing Association, pp. 316-322.

Stone, G.P. 1954. City shoppers and urban identification: observation on the social psychology of city life, American Journal of Sociology, 60(July): $36-45$

Tull, D.S. \& Hawkins, D.I. 1993. Marketing research: measurement and method. 6th ed. New York: MacMillan Publishing.

Tauber, E.M. 1972. Why do people shop? Journal of Marketing, 36(4): 46-49.

Watt, I. 1999. Trends in shopping centre and retail developments. Planning, XX January/February: 5-8

Westbrook, R.A. \& Black, W.C. 1985. A motivation-based shopper typology, Journal of Retailing, 61(1): 78-103. 